\title{
Research on Innovation Mode of the Financial Management in Enterprise Groups at theTransformation Period in China
}

\author{
Bei Lyu \\ Panyapiwat Institute of Management \\ Nonthaburi, Thailand 11120
}

\begin{abstract}
Since the reform and opening-up, Chinese economy has developed vigorously, and numerous enterprise groups have appeared. However, when the national economy enters new transformation period, it has higher requirements for alliance, merger and acquisition of group industry, the system of modernized enterprise group and the financial management mode. Therefore, the financial management mode must develop according to specific national conditions, market condition and actual operation of enterprise group. This paper first elaborates three financial management modes of enterprise group, proposes factors that influence financial management mode and problems in financial management of enterprise groups, and the methods to solve problems in financial management, namely the innovation mode for financial management of enterprise group.
\end{abstract}

Keywords-enterprise group; financial management mode; innovation mode

\section{INTRODUCTION}

With the continuous vigorous social and economic development, enterprise groups under socialist market system also improve constantly. The improvement of financial management mode and system helps enterprise groups to effectively manage financial information and has significance on long-term development of enterprise group. However, the financial management mode of enterprise groups has deficiencies and higher requirements for financial management staff under modernized management environment. Therefore, at present, financial management personnel must consider how to improve the current financial management mode of enterprise groups.

\section{INTRODUCTION TO FINANCIAL MANAGEMENT MODE OF ENTERPRISE GROUP}

\section{A. Definitions of Enterprise Group and Financial Management}

Enterprise group is the advanced organization form of modern enterprise, referring to super enterprise that centers on one or several large-scale enterprises with powerful strength and the function of investment center. [1] Core enterprise (parent company) and subsidiary company have inseparable connection in asset allocation, capital operation and technological innovation. Besides, they form a stable multilayer economic organization through personnel arrangement, property holding and business cooperation. Financial management mode refers to the financial management system of enterprise group. In the frame of enterprise management, in order to achieve the overall financial objective of enterprise group, the financial management mode, organizational labor division and management organization are combined, including the classification of jurisdiction in financial decision-making between parent company and subsidiary company. Specifically, it contains financing decision-making, funds management, investment decision-making, assets disposal and income distribution. [2] At the meantime, financial management has diversified financial management objective, complicated financial management contents and open financial management environment. [6]

\section{B. Financial Management Mode}

At present, there are three financial management modes generally accepted by people, including power centralization mode, power separation mode and integration mode. [3]

1) Power centralization mode: The power centralization mode of financial management means financial decisionmaking rights of enterprise group center on the group company (parent company), which carries out centralized implementation and management. Controlled companies subordinate to the group company execute in strict accordance with regulations of the group company. The parent company of group enterprise has decision-making power of financial management. Subsidiary company actively cooperates to perform financial decision-making of the parent company. Because the financial management rights of enterprise group (parent company) are highly centralized, it can guarantee the big decisions of financing and merger and acquisition of enterprise group and effectively reduce the administration cost and command cost. The financial decision-making mode has advantages. The financial decision-making of parent company is highly authoritative, effectively reducing operational risk of subsidiary company and actively copes with the complicated and ever-changing financial competitive environment. The mode of "the below following the behavior of the above" 
makes typical contribution to the standardized management of enterprise.

2) Power separation mode: The power separation mode of financial management refers to the balance of financial management rights between parent company and subsidiary company. The parent company of enterprise group focuses on strategic direction of enterprises. Subsidiary company has rights to supplement decision-making in welfare and treatment of employees and financial use. Parent company respect and encourage the production and operation of subsidiary company within certain administration authority. The financial decision-making mode also has advantages. Subsidiary company has autonomous right of financial operation, but excessive financial decentralization will have negative influence on enterprises. For example, subsidiary company may set a private coffer without permission, weakening the competitiveness of enterprise group.

3) Integration mode: The integration mode of financial management refers to the financial management mode that integrates the power centralization mode and the power separation mode. Enterprise group (parent company) gives independent management rights to subsidiary company according to product brand, customers and service region. Parent company and subsidiary company can adjust according to physical truth of market. Parent company supports and coordinates roundly. Subsidiary company can operate creatively and verify the actual effects of financial management decision of parent company. If the financial management rights of parent company are excessively centralized, it will disturb the independent operation of subsidiary company. If the financial management rights of subsidiary company are enlarged excessively, it will make the financial management rights of parent company in enterprise group out of control.

\section{ANALYSIS ON FACTORS THAT INFLUENCE FINANCIAL MANAGEMENT MODE OF ENTERPRISE GROUP}

\section{A. The Organization Structure of Enterprise Group}

Modern enterprise management forms have different internal organization structures such as management structure of radioactive rays and management structure of line segment, showing the power centralization of financial management mode and power separation of financial management mode in enterprise group.

\section{B. The Development Strategy of Enterprise Group}

To seek development, enterprise group must carry out strategic development and can formulate scientific and reasonable financial strategic objective under the guidance of scientific strategy. The development of parent company is more comprehensive and important than that of subsidiary company. Besides, it relates to construction mode of enterprise and the diversified business mode.

\section{The Limitation of Enterprise Group at Different Development Stages}

Enterprises experience many periods from establishment to development. The financial management mode of it also transform from power centralization to power separation. With continuous development of enterprise group, both market and investor propose better supervision requirement for financial management of group. They can effectively avoid risk according to economic benefit of market.

\section{Internal and External Economic Environment of Enterprise Group}

All economic factors that influence financial management of enterprises are called economic environment, including economic plan of government, overall economic situation and the relation between supply and demand. [7] Chinese economy and society develop rapidly. In order to adapt to social and economic development, enterprises also constantly expand production. Internal economic demand and external economic fluctuation of enterprise will influence financial management. Financial controller must take scientific and effective measures of risk prevention.

\section{PRoBlems In FinANCIAL MANAgEMENT ModE OF ENTERPRISE GROUP}

\section{A. Financial Controller of Enterprise Doesn't Update Idea}

Chinese people are influenced by planned economy for a long time, so many financial staffs are conservative and fail to consider time value and opportunity cost. The enterprise group will become "large and hollow" because it becomes mature in the recent ten years and the financial management is unscientific. Besides, it doesn't consider capital structure and investment risk budget. Financial management personnel of subsidiary company and parent company have different development objectives.

\section{B. The Objective of Enterprise Financial Management Is Unclear}

It is because participants of business entity fail to reach consensus on the final conclusion, which goes against the enterprise development; the objectives of parent company are not suitable to actual circumstances of subsidiary company, greatly damaging enterprise benefit.

\section{The Financial Management System of Enterprise Is Unsound}

The antiquated financial management system cannot meet demands of financing, merger and acquisition. The financial reports fail to accurately reflect real financial information. Internal and external inconsistency also damages enterprise benefit.

\section{Financial Management Operation of Enterprise Is Nonstandard}

Enterprise grouping develops rapidly, which leads to insufficient capital source of enterprises. Some enterprises depend on bank loan but lack systematic management and 
guidance of investment, so they cannot effectively use capital. Furthermore, enterprises lack uniform planning and effective budget, making enterprise financial operation more nonstandard.

\section{E. The Financial Management Supervision of Enterprise Is Unsound}

The traditional financial management cannot cope with modernized financial phenomenon. The financial information reported by subsidiary companies is non-transparent. The information transferred is inauthentic. Besides, supervision and audit are formalistic and go through the motions. Therefore, enterprises neither effectively supervise financial management nor establish effective financial evaluation system. [8]

\section{INNOVATION MODE OF FINANCIAL MANAGEMENT IN ENTERPRISE GROUP}

\section{A. Establish New Type of Thought in Financial Management}

Enterprise managers must bring financial management in enterprise strategy. Subsidiary and parent companies of the whole group formulate uniform financial development strategy. Financial management should occupy an important position in strategic planning of enterprise group. Financial budget including the budget of subsidiary company must be implemented. At the meantime, subsidiary companies must strictly execute financial budget and realize "rule by law" instead of "rule by man".

\section{B. Establish Proper Financial Management Objective of Enterprise Group}

When formulating financial objective, senior enterprise leaders must be practical and realistic, scientifically and reasonably set financial goals. Finance department of enterprise group can intervene and participate in formulating financial goals. Analysis of budget variances must be implemented actively.

\section{Establish Accurate Control System of Enterprise Group}

In order to strengthen and standardize financial management of enterprise group, improve level of operation and management and risk resistance ability of enterprise group as well as promote sustainable development of enterprise group, five ministries and commissions including Ministry of Finance of the People's Republic of China issued Basic Norms of Enterprise Internal Control in 2008, issued Guide on Enterprise Internal Control in 2010, jointly establishing the standardized system of Chinese enterprise internal control. [8] It achieves the mutual coordination and unification of financial systems in parent company and subsidiary company, the consistency of approval in parent company and subsidiary company. Meanwhile, they effectively avoid the randomness in policy formulation, compile monthly, quarterly and annual financial budget and annual audit system, as well as establish multilayer incentive and scientific restraint system.

\section{Establish Sound Internal Financial Supervision of Enterprise Group}

Parent company of enterprise group must carry out internal financial audit according to external audit, make the best of intermediary organs, clearly grasp capital situation of subsidiary companies and implement unified management and distribution.[4] The control system with the power centralization as dominant role the power separation as an auxiliary is established. Moreover, financial management system of enterprise group can be dynamically adjusted.

\section{E. Establish Open and Intelligent Financial Information of Enterprise Group [5]}

Bidirectional and dynamic data management platform must be established. Financial management adheres to the principles of information systematization and two-way communication. Subsidiary companies can submit financial information to parent company. Parent company carries out information management interaction through summarizing financial information submitted by subsidiary companies. Meanwhile, enterprise group can realize internal online financial management to further improve efficiency of financial management and information feedback, effectively form resultant force of local area network in financial management and realize efficient decision-making of financial management.

\section{F. Reduce Personnel and Improve Efficiency among Financial Management Personnel of Enterprise Group}

In enterprise group, there are various financial organizations, many and diverse personnel and unscientific separation of duties. The financial management professionals have inferior status and small power in enterprise group. Financial management affairs are determined by enterprise leaders. It violates the law of market economic development. It does not promote sound development of enterprises but impedes it. Therefore, it is imperative for financial management organizations to reduce personnel and improve efficiency, design market-oriented internal financial management organization and improve practical efficiency of financial management.

\section{G. Integrate Enterprise Culture with Financial Management System [9]}

Enterprise culture is the core vitality and competitiveness of enterprise, ensures enterprise stability and development and gathers enterprise wisdom. Organic integration of financial management in enterprise group and enterprise culture will effectively implement financial management system.

\section{CONCLUSION}

The factors influencing financial management mode of enterprise group and problems in financial management are proposed. Innovation suggestions are proposed to change the current situation of financial management, such as financial controller of enterprise doesn't update idea, the objective of enterprise financial management is unclear, the financial management system of enterprise is unsound and financial 
management operation of enterprise is nonstandard. Enterprises can establish new type of thought in financial management, proper financial management objective, accurate control system, sound internal financial supervision, open and intelligent financial information, and reduce personnel and improve efficiency among financial management personnel and integrate enterprise culture with financial management system, in order to seek development through innovation modes.

\section{REFERENCES}

[1] Li Qiong. Discussion on Financial Management Mode of Modern Enterprises [J], Technological Development of Enterprise, 2007, (6): 34

[2] Sun Yuehua. Analysis on Financial Management Mode of Enterprise Group [J], Modern Magazine of Industry and Commerce, 2011, (6): 2-4

[3] Huang Keyan. Research on Financial Management Mode of Enterprise Group [J], Economic Research Guide, 2017, (1): 105-107

[4] Zhang Jing. Analysis on Characteristics of Financial Management of Enterprise Group [J], Modern Economic Information, 2017, (2): 265

[5] Ji Xinhua. Discussion on Informatization of Financial Management of Enterprise Group [J], Communication of Finance and Accounting, 2016(23): 47-49

[6] Wang Weiping. Analysis on Financial Management Mode of Enterprise Group under Modern Management Situation [J], Productivity Research, 2016(4): 156-160

[7] Tian Feng. Analysis on Innovation Management Mode of Finance Company of Enterprise Group and Performance Evaluation [J], Modern Property Management, 2014, 4(12): 20-22

[8] Lyu Yan. Thinking on Strengthening Financial Management of Group and Suggestions [J], China Journal of Commerce, 2017, (15): 85-86

[9] Liu Tingting. Analysis on Innovation of Management System of Modern Enterprise [J], China Business and Trade, 2011(21): 86-87 